\title{
Prevalence, molecular detection and risk factors investigation for the occurrence of Toxoplasma gondii in slaughter pigs in North India
}

\author{
Rashmi Thakur *i(B, Rajnish Sharma, R. S. Aulakh, J. P. S. Gill and B. B. Singh
}

\begin{abstract}
Background: Toxoplasma gondii, an important food borne zoonotic parasite, infects almost all warm-blooded animals including pigs. People primarily become infected with $T$. gondii via consuming meat of infected animals. Status of T. gondii is largely unknown in pigs in India including northern regions. We, therefore, determined the prevalence of $T$. gondii infection in pigs from North India.

Results: DNA of T. gondii was detected in 6.7\% (54/810) of the tested slaughter pigs. Highest prevalence was observed in pigs from Punjab (8.2\%) followed by Chandigarh (5.3\%) and Uttarakhand (4.8\%). Phylogenetic analysis revealed that the isolates from pigs had 96-100\% nucleotide identity with Type I RH strain (AF179871), 96-99.7\% with VEG type III strain (LN714499) and 67-72\% with type II ME 49 strain (XM002370240). However, low level of polymorphism in the targeted B1 gene did not allow the determination of the clonal lineages of the isolates. Antibodies against T. gondii was reported in 48.3\% (73/151) of the sera obtained from pigs slaughtered at Chandigarh abattoir, and scavenging by pigs was a significant risk factor.

Conclusion: Prevalence of T. gondii DNA was low in pigs in North India, however, presence of the parasite warrants food safety concerns. Further studies are required to identify the clonal lineage of $T$. gondii circulating in pigs reared in North India. Pig farmers should be educated about the hygienic management practices.
\end{abstract}

Keywords: India, Pigs, Prevalence, Toxoplasma gondii, Zoonosis

\section{Background}

Toxoplasmosis is caused by T. gondii, a zoonotic protozoan parasite which can infect almost all warm-blooded animals, including people. One third of human population worldwide has been exposed to $T$. gondii once in their life [16, 30, 31]. Infected people are usually symptomless or may have fever, malaise, myalgia, headache and lymphadenopathy [11]. Globally, 190,100 annual cases of congenital toxoplasmosis have been reported, leading to 1.20 million DALYs (Disability adjusted life years) and 1.5 cases of congenital toxoplasmosis per 1000 live births [40]. In India, 56,737 and 176,882 children are born with a possible risk of congenital

\footnotetext{
* Correspondence: thakur.rashmi28@gmail.com

School of Public Health and Zoonoses, Guru Angad Dev Veterinary and Animal Sciences University, Ludhiana, Punjab 141004, India
}

toxoplasmosis every year [36]. Seroprevalence of $22 \%$ in pregnant women was reported [35]. First nationwide survey on $T$. gondii infection in humans in India conducted in 2005 indicated a seroprevalence of 24\% (5611/ 23094) [9]. In North India, sero-prevalence was highest in Chandigarh (20\%) followed by Uttar Pradesh (19\%); prevalence was $13 \%$ in people of Punjab [9].

Animals play a pivotal role in the life cycle of $T$. gondii and its transmission to people. Felids are the only definitive hosts, which excrete oocysts of $T$. gondii in their faeces. Rodents and birds are the intermediate hosts in the natural life cycle of $T$. gondii; almost all warm-blooded animals (sheep, goat, cattle, pigs etc.) can also act as intermediate hosts. Intermediate hosts including people become infected via (1) consuming food and/ water contaminated with oocysts, (2) transplacental transmission

(c) The Author(s). 2019 Open Access This article is distributed under the terms of the Creative Commons Attribution 4.0 International License (http://creativecommons.org/licenses/by/4.0/), which permits unrestricted use, distribution, and reproduction in any medium, provided you give appropriate credit to the original author(s) and the source, provide a link to the Creative Commons license, and indicate if changes were made. The Creative Commons Public Domain Dedication waiver (http://creativecommons.org/publicdomain/zero/1.0/) applies to the data made available in this article, unless otherwise stated. 
(3) ingesting meat containing bradyzoites of T. gondii [16]. Ingestion of infected raw or inadequately cooked meat is considered a significant route of transmission in people. In a multicentric study in Europe, consumption of meat was considered as a potential risk of $T$. gondii infection [7]. It, therefore, becomes important to determine the status of $T$. gondii in the meat producing animals.

Several studies have been conducted in meat producing animals in India, and the prevalence varied from 1 to $85 \%[18,22]$. Only few studies detected the presence of $T$. gondii in pigs in India. Pigs are important for food security in India. As per the 19th livestock census, there are 10.29 million pigs in India [3]. The demand for pork has increased manifolds over the past few years. In India, most of the people involved in pork production belong to poor strata and thus, pork production is carried out under unhygienic conditions with low input costs exposing pigs to various infections [6]. Pigs reared are often allowed to roam freely and scavenge on unhygienic areas such as garbage disposal sites [6]. Such management practices can expose pigs to the zoonotic food borne parasites including $T$. gondii. To best of our knowledge, three studies have been conducted on $T$. gondii infection in pigs in India and two of them were based on serology i.e. detection of antibodies to T. gondii $[4,34]$. Presence of anti T. gondii IgG in pigs indicates if they have been exposed to the parasite but does not tell about the presence of active infection, which becomes important especially for food safety concerns. Therefore, the primary aim of the current study was to detect DNA of T. gondii in the muscle tissues of pigs slaughtered for human consumption in North India. Previous research in pigs in India did not involve identification of the potential risk factors for the exposure to T. gondii. Such information is of utmost importance to develop and implement effective control strategies to combat food borne zoonotic parasites including $T$. gondii. To fill this knowledge gap, second aim of the current study was to investigate the seroprevalence of $T$. gondii and its association with the potential risk factors (for example age, sex and management practices) in the pigs slaughtered in an abattoir in Chandigarh.

\section{Results}

Prevalence of $T$. gondii in pigs from North India

DNA of $T$. gondii was detected in 54 of the slaughtered pigs indicating an overall apparent prevalence of $6.7 \%$ (95\% CI $=5-9 \%)$ in North India. Prevalence was highest in province of Punjab $(8.2,95 \% \mathrm{CI}=6.0-11.2 ; 35 / 427)$ followed by Chandigarh $(5.3,95 \% \mathrm{CI}=2.7-10.1 ; 8 / 151)$ and Uttarakhand $(4.7,95 \% \mathrm{CI}=2.7-8.3 ; 11 / 232)$. District wise prevalence of $T$. gondii in pigs is provided in the Table 1.

\section{Sequencing and phylogenetic analysis}

The phylogenetic tree based on the alignment of B1 gene indicated that all positive samples except $55 \mathrm{~T}$ of the study were clustered with the VEG type III strain (LN714499) and unverified sequence EU341713 from Chennai, India; however sequence of positive sample 55 $\mathrm{T}$ of the current study clustered with unverified sequence KKF425004 MU1B1 Thailand (Fig. 1). The sequence alignment score of six sequences showed 96100\% nucleotide identity with Type I RH strain (AF179871) and VEG type III strain (LN714499) and $67-72 \%$ identity with Type II ME 49 strain (XM002370240). However, low level of polymorphism in the targeted B1 gene did not discriminate the clonal lineages of isolates identified in the current study.

\section{Seroprevalence and associated risk factors in pigs slaughtered at Chandigarh abattoir}

Antibodies to T. gondii were detected in 73 (48.3, 95\% $\mathrm{CI}=40.5-56.3)$ of the 151 pigs tested; 3 animals showed

Table 1 Prevalence of T. gondii in naturally infected pigs from North India

\begin{tabular}{|c|c|c|c|c|}
\hline Location & Total number of samples & PCR positives & Apparent prevalence (\%) & 95\%confidence interval (Cl) \\
\hline Punjaba & 427 & 35 & 8.2 & $6-11$ \\
\hline Ludhiana $^{b}$ & 113 & 7 & 6.19 & $3-12$ \\
\hline Jalandhar ${ }^{b}$ & 154 & 22 & 14.2 & $10-21$ \\
\hline Bathinda ${ }^{b}$ & 90 & 4 & 4.44 & $2-11$ \\
\hline Patialab & 70 & 2 & 2.85 & $1-10$ \\
\hline Chandigarh $^{a}$ & 151 & 8 & 5.29 & $3-10$ \\
\hline Uttarakhand ${ }^{\mathrm{a}}$ & 232 & 11 & 4.7 & $3-8$ \\
\hline Udham Singh Nagar ${ }^{c}$ & 07 & 0 & 0 & $0-0.35$ \\
\hline Nanital $^{\mathrm{C}}$ & 225 & 11 & 4.88 & $3-9$ \\
\hline North India & 810 & 54 & 6.67 & $5-9$ \\
\hline
\end{tabular}

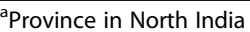

${ }^{b}$ Districts selected in Punjab

'Districts selected in Uttaranchal 


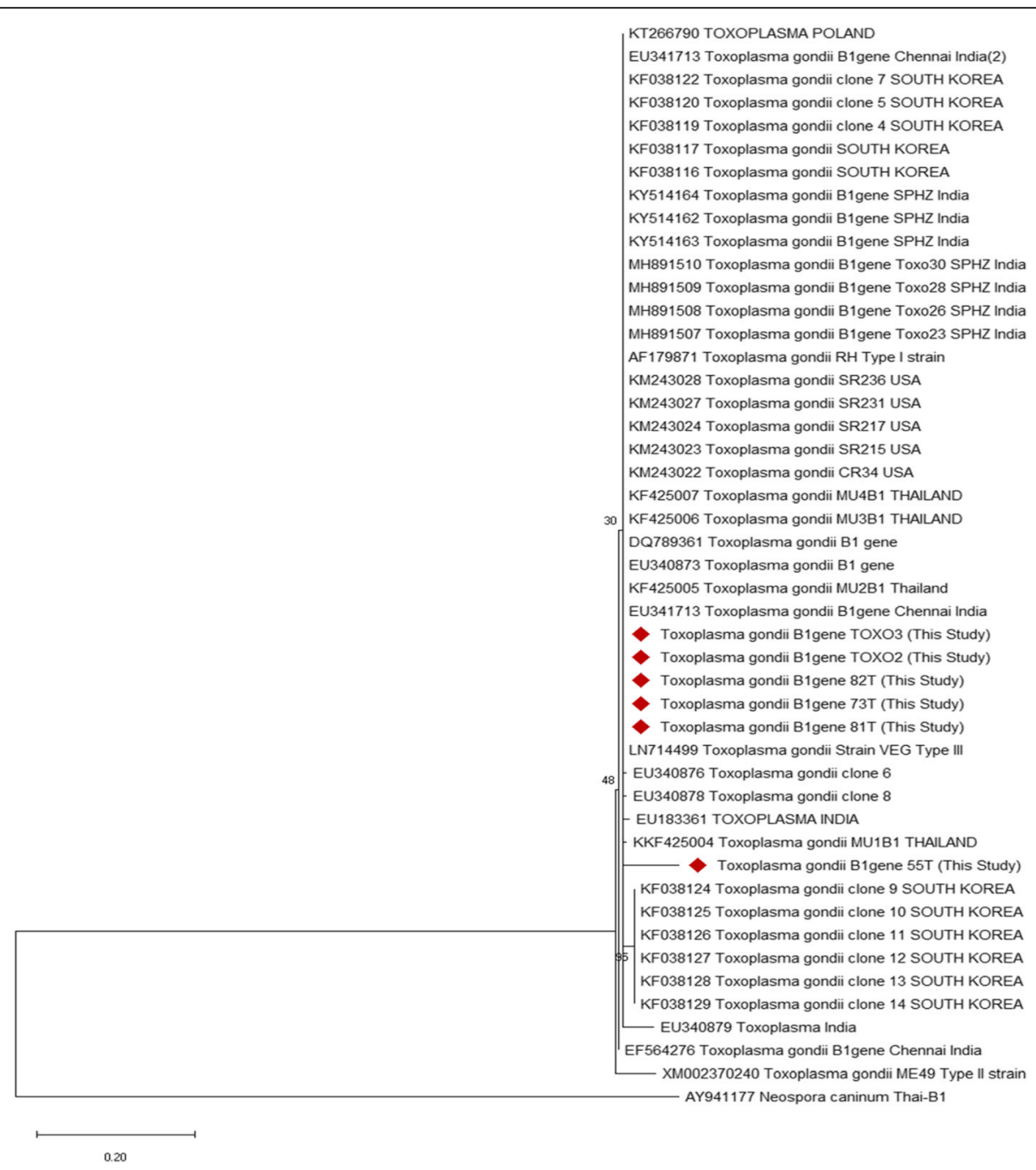

Fig. 1 Phenogram construction of the B1 gene of T. gondii isolates from naturally infected pigs along with reference strains

doubtful results and were not included in further analysis. Antibodies to $T$. gondii were detected more frequently in pigs $<3$ months $(65 \%, 11 / 17)$ than pigs $>6$ months $(47 \%, 62 / 131)$. Almost equal proportion of males $(50 \%, 11 / 22)$ and females $(49 \%, 62 / 126)$ were anti- $T$. gondii antibody positive. Seroprevalence of T. gondii exposure did not differ significantly between age (Chi sq. = 1.818, $\mathrm{df}=1, p=0.178)$ and sex of pigs (Chi sq. $=0.05$, $\mathrm{df}=1, p=0.945$ ). Higher seroprevalence was reported in pigs that were allowed scavenging $(58 \%, 73 / 125)$ than those that were not allowed; management practices were significantly associated with $T$. gondii exposure (Chi sq. $=26.5, \mathrm{df}=1, p=<0.05$ ).

\section{Comparison between PCR and ELISA}

Out of 151 pigs tested for antibodies against (using ELISA) and DNA of (using PCR) T. gondii, 73 and 8 were positive, respectively. Of $8 \mathrm{PCR}$ positives, all were ELISA positives, however, of 140 PCR negatives, 65 were
ELISA positives. ELISA showed poor agreement (Kappa $=0.11,95 \% \mathrm{CI}=0.03-0.18)$ with PCR.

\section{Discussion}

We document the first report of detection of DNA of $T$. gondii in pigs in India. Previously, DNA of T. gondii was detected in other meat producing animals (e.g. sheep, goat and poultry) from India $[2,27,33]$. Methods for detection of $T$. gondii or its DNA include bio-assays, tachyzoite culture, immunohistochemistry and PCR [29]; all but PCR are labour intensive and time consuming. PCR was used to detect $T$. gondii DNA in the tissues of pigs, but this method does not detect the viability of the parasite. Previously, viable $T$. gondii has been isolated from pork in Haryana, another north Indian state and elsewhere [14, 22, 32]. Further studies are required to isolate viable $T$. gondii in the pork samples destined for human consumption from North India. Overall, the presence of T. gondii DNA in the tissues of the pigs which were 
destined to human consumption presents a public health risk in North India. Hence, cooking pork adequately before consumption is highly recommended.

B1 gene, targeted for detection of T. gondii DNA in the current study, is a multi-copy sequence specific and highly conserved gene in all $T$. gondii strains [39], which makes it highly useful in molecular detection of parasite [37]. The phylogenetic analysis based on B1 gene showed clustering of positive samples with the VEG type III strain (LN714499) (Fig. 1). However, low level of polymorphism in B1 gene [28] did not discriminate the clonal lineages of different isolates obtained. Further studies are required to determine the genotypes of $T$. gondii circulating in the pigs of India.

A low prevalence of $7 \%$ recorded in the pigs in current study was comparable with the prevalence reported in sheep, goat (4-6\%) and poultry (5\%) in India [2, 27, 33]. This low prevalence could be attributed to false negative results due to use of small amount of tissue sample (200 ul) for extracting DNA in the current study. Low level of infection in pigs was reported in T. gondii infected pigs in a previous study, where one tissue cyst per $50 \mathrm{~g}$ of host tissue was detected [17]; however, the parasitic load was not quantified, presumably lower infection intensity in samples could be a possible explanation for low prevalence. Moreover, most common predilection sites for $T$. gondii in pigs include brain and heart followed by tongues; leg muscles have lower amount of the parasites $([19,26])$. Tongues or ham muscles were used for the detection of $T$. gondii in this study. Due to the afore mentioned reasons, prevalence estimated in the current study could be an under estimate of actual prevalence of $T$. gondii in the pork samples from north India, therefore further studies should use more sensitive techniques like magnetic-capture PCR ([26]) and common tissue predilection sites (brain and heart).

Surveys conducted in pigs globally recorded seroprevalence varied from 0 to $92.7 \%$ ([5, 15];). High seroprevalence of T. gondii in pigs (48\%) from Chandigarh was corroborated with other reports in pigs from India India and elsewhere $[4,32]$. However, low seroprevalence was reported in pigs from Haryana, another north Indian state [34]; this variation in seroprevalences could be attributed to difference in the serological methodology, geography, management practices and sample size. Of 73 sero-positive pigs from Chandigarh, 6 were positive for the presence of T. gondii DNA, which indicated poor agreement between ELISA and PCR. Moreover, sero-prevalence of antibodies to T. gondii in pigs in India $[15 \%$ in pigs from Haryana (northern state) [34], 32\% in pigs in the North Indian [4], and 48\% in pigs in current study] was higher than prevalence (of T. gondii DNA) in pigs in current study. Higher seroprevalence (of $T$. gondii antibodies) compared to prevalence (of $T$. gondii DNA) was expected as serology indicates exposure to pathogen not infection. On the other side, serology if detects IgG only can miss the acute infection and may lead to false negatives, therefore, a combination of molecular and serological tests can improve the diagnosis of $T$. gondii.

Scavenging by pigs was a potential risk factor for their exposure to $T$. gondii. Similar to our findings, higher seroprevalence was noticed in free ranging scavenging pigs in other parts of the world, e.g. Central Ethiopia, Netherlands, Zimbabwe [21, 25, 41]. Free ranging pigs have more exposure to $T$. gondii from the environment (contaminated food/water with oocysts, contaminated soil by rooting, infected meat scarps outside meat shops, consuming infected rodents). Previous studies in Brazil, USA and China found other potential risk factors for $T$. gondii exposure in pigs; for example, the presence of cats in or around farms, rodent control, carcass disposal and feeding leftovers $[20,24,38]$.. Such information was not available for the pigs from Chandigarh; further epidemiological studies in pigs in India should also include these potential risk factors.

In India, $70 \%$ of the pig population is raised under traditional small holder, low-input demand driven production systems, except for limited number of semicommercial pig farms in Kerala, Punjab and Goa [3]. In India, pig farming is largely done by the people with low socio-economic status [6]. Pigs are reared in poor hygienic conditions and have free access to garbage and stray animals (cats and dogs) or rodents, so they have higher chances of becoming infected with or exposed to T. gondii. Clinical manifestations are usually absent in pigs infected with Toxoplasma gondii, however have been reported especially in young pigs $[10,12,15]$. Reproductive losses (abortion and neonatal mortality) have been seen in sows infected with $T$. gondii $[10,12$, 15]. Toxoplasmosis in pigs may lead to major economic losses to pig farmers. Therefore, pig farmers should be educated about good hygienic practices to raise healthy and disease-free pigs, which will help preventing economic losses as well as food borne zoonoses.

\section{Conclusion}

The presence of $T$. gondii in pig meat from North India raises a public health concern, especially in free ranging scavenging pigs. Pig farmers should be educated about the hygienic management practices of pig farming. Cooking pork adequately before consumption is highly recommended. As infected meat producing animals including pigs are the direct source of infection to people, policies should be developed for routine screening of animals for $T$. gondii. Additional studies are necessary to isolate viable $T$. gondii from pork from India, and to determine the genotypes of $T$. gondii circulating in pigs. 


\section{Methods}

\section{Study area}

The study area included Punjab (Latitude of $30^{\circ} 4^{\prime} \mathrm{N}$ and Longitude $75^{\circ} 5^{\prime} \mathrm{E}$ ), Uttarakhand (Latitude of $30^{\circ} 15^{\prime} \mathrm{N}$ and Longitude $79^{\circ} 15^{\prime} \mathrm{E}$ ) and Chandigarh (Latitude of $30^{\circ} 44^{\prime} 14 \mathrm{~N}$ and Longitude $76^{\circ} 47^{\prime} 14 \mathrm{E}$ ); all three regions are from North India. Uttarakhand, established as a new province in 2000, was carved from Uttar Pradesh (another North Indian state). There are 22 and 13 districts in Punjab and Uttarakhand, respectively. Agriculture contributes significantly to the economy of both these northern states. Chandigarh is a union territory and capital of Punjab. As per the 19th livestock census of India, there are 32,221, 19,907 and 132 pigs in Punjab, Uttarakhand and Chandigarh, respectively [3]. The pig slaughter is primarily conducted in small slaughter shops in Punjab and Uttarakhand. Abattoir in Chandigarh is the only pig abattoir in Punjab, where pigs from Punjab and neighbouring states are slaughtered.

\section{Target and study population}

The target population primarily consisted of pigs slaughtered for human consumption in Punjab, Uttarakhand and Chandigarh. The study population included pigs slaughtered in four and two districts of Punjab and Uttarakhand, respectively as well as pigs slaughtered in Chandigarh abattoir. Six slaughter shops (one from each of the six districts [4 districts from Punjab: Jalandhar, Ludhiana, Bathinda, Patiala, and 2 districts from Uttarakhand: Udham Singh Nagar and Nanital]) were selected in Punjab and Uttarakhand; samples were collected from a pig abattoir from Chandigarh. The selection of shops in different districts or pigs in these shops was not random; however, we tried to ensure a loose representation by selecting slaughter shops in different areas and sampling on multiple occasions to ensure that pigs belong to different batches or pig owners.

\section{Sample size estimation}

Estimated sample size was 669; it was calculated using Statulator [8] to estimate prevalence at $95 \%$ confidence, a design effect of $2 \%$, and assumed prevalence of $32 \%$ based on a previous study [4].

\section{Collection of samples}

Tongue or ham muscles from 810 slaughtered pigs were collected from the shops of Punjab and Uttarakhand, and from an abattoir from Chandigarh (Table 1). Age $(<$ 3 months, $>6$ months), sex (male, female) and management practices (allowed scavenging or not) for individual pig slaughtered at Chandigarh abattoir was also recorded. Samples were transported to the laboratory at $20^{\circ} \mathrm{C}$.

\section{Pepsin- $\mathrm{HCl}$ digestion}

The pepsin- $\mathrm{HCl}$ digestion was performed as per Dubey [13]. Briefly, $50 \mathrm{~g}$ muscle after removing fat and connective tissue was chopped into small pieces and grinded for $15 \mathrm{~s}$ at slow speed in a blender followed by addition of $125 \mathrm{ml}$ of normal saline solution and blending at highest speed for $30 \mathrm{~s}$. Homogenate obtained was transferred to a $1 \mathrm{~L}$ beaker and pre-warmed $\left(37^{0} \mathrm{C} ; 250 \mathrm{ml}\right)$ acid pepsin solution (pepsin 1:10000, HiMedia; 2.6 g, NaCl 5 g, $\mathrm{HCl}$ $7 \mathrm{ml}$ and distilled water up to $500 \mathrm{ml}$ ) was added and incubated at $37^{\circ} \mathrm{C}$ for $2 \mathrm{~h}$. Homogenized solution was filtered through a sieve with a gauze and transferred to 50 $\mathrm{ml}$ plastic centrifuge tube. Centrifugation at $12,00 \mathrm{rpm}$ for $10 \mathrm{~min}$ was performed and supernatant was discarded. Pellet was re-suspended in $5 \mathrm{ml}$ of normal saline solution and stored at $-20{ }^{\circ} \mathrm{C}$ till further use.

\section{DNA extraction}

DNA was extracted from $200 \mu$ of re-suspended pellet using a commercially available kit (QIAamp DNA mini extraction kit, Qiagen, Netherlands) as per the manufacturer's instructions and stored at $-20^{\circ} \mathrm{C}$ until further analysis.

\section{Nested- polymerase chain reaction (nested PCR)}

To detect DNA of Toxoplasma gondii, primers amplifying $\mathrm{B} 1$ gene were used in a nested PCR assay as per previous protocol [23]. In each PCR assay, known positive (T. gondii DNA) and negative controls (nuclease free water) were used. DNA of $T$. gondii was provided by the Department of Parasitology, Post Graduate Institute of Medical Education and Research, Chandigarh.

\section{Phylogenetic analysis}

PCR products of six positive samples were purified using Wizard $^{\odot}$ SV Gel and PCR Clean-Up System (Promega Biotech, India) as per manufacturer's guidelines. The eluted DNA samples were sent for sequencing (Singapore). For analysing the sequencing results NCBI BLAST software was used [1] and the aligned dataset of B1 gene of $T$. gondii was analysed by Molecular Evolutionary Genetics Analysis (MEGA) software version X. The six B1 coding sequences (Toxo 2, Toxo 3, 55 T, 73 $\mathrm{T}, 81 \mathrm{~T}, 82 \mathrm{~T}$ ) obtained in the current study were compared with the previously published B1 coding sequences [RH type I strain (AF179871), ME49 type II strain (XM002370240),VEG type III strain (LN714499)] and other 37 non-typing T. gondii B1sequences available in the GeneBank database. Neospora caninum B1 coding sequence of glycerol-3-phosphate dehydrogenase 1 (GPDH-1) similar to $T$. gondii was used as an out group for comparison. Phylogenetic tree was constructed with Maximum Likelihood (ML) method using Tamura-Nei model. 


\section{Enzyme linked Immunosorbent assay (ELISA)}

Using commercially available Toxoplasma ELISA kit (PrioCHECK ${ }^{\circ}$ Toxoplasma Ab porcine), sera collected from pigs $(n=151)$ slaughtered in Chandigarh abattoir were tested for the presence of anti-Toxoplasma antibodies as per manufacturer's guidelines.

\section{Statistical analysis}

\section{Prevalence and seroprevalence}

Apparent prevalence and seroprevalences were calculated from the proportion of positive results of those tested by PCR and ELISA, respectively, and were presented with $95 \%$ confidence intervals.

\section{Association between sero-status and risk factors}

On the subset of pigs (pigs slaughtered at Chandigarh abattoir) that were tested for $T$. gondii antibodies, the associations between outcome variable (either seropositive/negative for $T$. gondii antibodies) and the predictors [age ( $<3$ months, $>6$ months), sex (female and male) and management practices (allowed scavenging or not)] were determined using Chi square test. The doubtful results $(n=3)$ on ELISA were excluded in this analysis.

\section{Comparison between PCR and ELISA}

The kappa value (k) was calculated to determine the agreement between PCR and ELISA. Kappa values of $\leq 0.40,0.40-0.60,0.61-0.80$ and $\geq 0.81$ were considered to indicate slight to poor, moderate to good, substantial and excellent agreement, respectively [42]. All statistical analyses were performed using IBM SPSS (ver. 24; Armonk, New York, USA).

\section{Abbreviations}

DALYs: Disability adjusted life years; ELISA: Enzyme linked Immunosorbent Assay; GPDH-1: Glycerol-3-phosphate dehydrogenase 1; MEGA: Molecular Evolutionary Genetics Analysis; ML: Maximum Likelihood; PCR: Polymerase Chain Reaction

\section{Acknowledgements}

The authors also wish to thank Department of Parasitology, PGIMER Chandigarh for providing T. gondii standards.

\section{Authors' contributions}

BBS, RSA and JPSG conceived and designed the study. RT performed the lab work. RS performed statistical analysis and interpreted the data. RS and RT drafted the manuscript. RT, RS, RSA, JPSG and RSA revised the manuscript. All authors read and approved the final manuscript. BBS led the research project.

\section{Funding}

The financial support received from Indian Council of Medical Research through research project "Molecular epidemiology of porcine Trichinellosis and Toxoplasmosis in India: addressing neglected zoonotic diseases in a one health context" (Grant number ZON/22/01/2017-ECD-II) is thankfully acknowledged. The funding agency had no role in the design of the study and collection, analysis, and interpretation of data and in writing the manuscript.

\section{Availability of data and materials}

The datasets used and/or analysed during the current study available from the corresponding author on reasonable request.

\section{Ethics approval and consent to participate}

The current study was approved by the Institutional Ethics Committee, Guru Angad Dev Veterinary and Animal Sciences University, Ludhiana (Approval number -IAEC/2015/97-129). The study was conducted from January 2017 to August 2018.

\section{Consent for publication \\ Not applicable.}

\section{Competing interests}

No financial or personal relationships between the authors and other people or organizations have inappropriately influenced (bias) this work.

Received: 13 January 2019 Accepted: 18 November 2019

Published online: 03 December 2019

\section{References}

1. Altschul SF, Gish W, Miller W, Myers EW, Lipman DJ. Basic local alignment search tool. J Mol Biol. 1990;215:403-10.

2. Anjali D, Vikrant S, Amit J, Amit S, Daya S. B1 gene based semi nested PCR for detection of toxoplasmosis from poultry hearts. Ind J Anim Sci. 2017; 87(8):980-1

3. Basic Animal Husbandry and Fisheries Statistics (BAHS), 2014. 19th livestock Census-2012, All India Report. Ministry of Agriculture Department of Animal Husbandry, Dairying and Fisheries, Government of India.

4. Chhabra MB, Mahajan RC. Occurrence of Toxoplasma gondii in slaughter pigs in India. Trop Geogr Med. 1979;31:123-6.

5. Chandrawathani $P$, Nurulaini $R$, Zanin $C M$, Premaalatha $B$, Adnan $M$, Jamnah O, Khor SK, Khadijah S, Lai SZ, Shaik MAB, Seah TC, Zatil SA. Seroprevalence of toxoplasma gondii antibodies in pigs, goats, cattle, dogs and cats in peninsular Malaysia. Trop Biomed. 2008;25:257-8.

6. Chauhan A, Patel BHM, Maurya R, Kumar S, Shukla S, Kumar S. Pig production system as a source of livelihood in Indian scenario: an overview. Int J Sci Environ Technol. 2016;5(4):2089-96.

7. Cook AJC, Gilbert RE, Zufferey J, Petersen E, Jenum PA, Foulon W, Semprini AE, Dunn DT. Source of Toxoplasma infection in pregnant women: European multicenter case control study. Br Med J. 2000;321(7254):142-7.

8. Dhand, N. K., \& Khatkar, M. S. (2014). Statulator: An online statistical calculator. Sample Size Calculator for Estimating a Single Proportion. http:// statulator.com/SampleSize/ss1P.html

9. Dhumne M, Sengupta C, Kadival G, Rathinaswamy A, Velumani A. National seroprevalence of Toxoplasma gondii in India. J Parasitol. 2007;93(6):1520-2.

10. Dubey JP. A review of toxoplasmosis in pigs. Vet Parasitiol. 1986;19:181-223.

11. Dubey JP. Toxoplasmosis--an overview. Southeast Asian J Trop Med Public Health. 1991;22(Suppl):88-92.

12. Dubey JP, Beattie CP. Toxoplasmosis of animals and man. Boca Raton: CRC Press; 1988. p. 1-220.

13. Dubey JP. Refinement of pepsin digestion method for isolation of toxoplasma gondii from infected tissues. Vet Parasitol. 1998;74:75-7.

14. Dubey JP, Hill DE, Jones JL, Hightower AW, Kirkland E, Roberts JM, Marcet PL, Lehmann T, Vianna MC, Miska K, Sreekumar C, Kwok OC, Shen SK, Gamble HR. Prevalence of viable Toxoplasma gondii in beef, chicken, and pork from retail meat stores in the United States: risk assessment to consumers. J Parasitol. 2005:91(5):1082-93.

15. Dubey JP. Toxoplasmosis in pigs- the last 20 years. Vet Parasitiol. 2009;164: 89-104.

16. Dubey JP. Toxoplasmosis of animals and humans. 2nd ed. Boca Katon: CRC Press Inc; 2010.

17. Dubey JP, Lunney JK, Shen SK, Kwok OC, Ashford DA, Thulliez P. Infectivity of low numbers of Toxoplasma gondii oocysts to pigs. J Parasitol. 1996;82(3): 438-43.

18. Dubey JP, Somvanshi R, Jithendran KP, Rao JR. High seroprevalence of Toxoplasma gondii in goats from Kumaon region of India. J Vet Parasitol. 1993;7(1):17-21.

19. Dubey JP, Murrell KD, Fayer R. Persistence of encysted Toxoplasma gondii in tissues of pigs fed oocysts. Am J Vet Res. 1984;45(10):1941-3. 
20. Feitosa TF, Vilela VL, de Melo LR, de Almeida Neto JL, Souto DV, de Morais DF, Athayde AC, Azevedo SS, Pena HF. Toxoplasma gondii and Neospora caninum in slaughtered pigs from northeast, Brazil. Vet Parasitol. 2014;202(34):305-9.

21. Gebremedhin EZ, Kebeta MM, Asaye M, Ashenafi H, Marco VD, Vitale M. First report on seroepidemiology of Toxoplasma gondii infection in pigs in Central Ethiopia. BMC Vet Res. 2015;11:59. https://doi.org/10.1186/s12917015-0384-y.

22. Gupta SL, Mahjan SK, Chhabra MB, Gautam OP. Latent infection of Toxoplasma in pigs of Hissar, Haryana. Ind J Vet Med. 1982;2(2):65-7.

23. Habibi GR, Imani AR, Gholami MR, Hablolvarid MH, Behroozikhah AM, Lotfi M, Kamalzade M, Najjar E, Esmaeil-Nia K, Bozorgi S. Detection and identification of Toxoplasma gondii type one infection in sheep aborted fetuses in Qazvin Province of Iran. Iran J Parasitol. 2012;7(3):64-72.

24. Hill DE, Haley C, Wagner B, Gamble HR, Dubey JP. Seroprevalence of and risk factors for Toxoplasma gondii in the US swine herd using sera collected during the National Animal Health Monitoring Survey (swine 2006). Zoonoses Public Health. 2010;57(1):53-9.

25. Hove T, Lind P, Mukaratirwa S. Seroprevalence of Toxoplasma gondii infection in domestic pigs reared under different management systems in Zimbabwe. Onderstepoort J Vet Res. 2005;72(3):231-7.

26. Jurankova J, Basso W, Neumayerova H, Balaz V, Janova E, Sidler X, Deplazes $P$, Koudela B. Brain is the predilection site of Toxoplasma gondii in experimentally inoculated pigs as revealed by magnetic capture and realtime PCR. Food Microbiol. 2014;38:167-70.

27. Kalambhe D, Gill JPS, Singh BB. Molecular detection of Toxoplasma gondii in the slaughter sheep and goats from North India. Vet Parasitol. 2017;241: 35-8.

28. Khan A, Su C, German M, Storch GA, Clifford DB, Sibley LD. Genotyping of Toxoplasma gondii strains from immunocompromised patients reveals high prevalence of type I strains. J Clin Microbiol. 2005;43(12):5881-7.

29. Liu Q, Wang ZD, Huang SY, Zhu XQ. Diagnosis of toxoplasmosis and typing of Toxoplasma gondii. Parasit Vectors. 2015:8:292.

30. Montoya JG, Liesenfeld O. Toxoplasmosis. Lancet. 2004;363:1965-76.

31. Robert-Gangneux F, Darde ML. Epidemiology of and diagnostic strategies for toxoplasmosis. Clin Microbiol Rev. 2012;25:264-96.

32. Samico-Fernandes EFT, Samico-Fernandes MFT, de Albuquerque PPF, de Almeida JC, de Souza SA, da Rocha MA, de Souza Neto OL, Mota RA. Toxoplasma gondii in backyard pigs: seroepidemiology and mouse bioassay. Acta Parasitol. 2017;62(2):466-70. https://doi.org/10.1515/ap-20170054.

33. Satbige AS, Bharathi MV, Ganesan PI, Sreekumar C, Rajendran C. Detection of toxoplasma gondii in small ruminants in Chennai using PCR and modified direct agglutination test. J Parasit Dis. 2016;40(4):1466-9. https:// doi.org/10.1007/s12639-015-0713-x.

34. Sharma SP, Gautam OP. A note on the prevalence of toxoplasma antibodies among camels and pigs in Hissar. Ind J Anim Sci. 1974;44(3):214-5.

35. Singh S, Munawwar A, Rao S, Mehta S, Hazarika NK. Serologic prevalence of Toxoplasma gondii in Indian women of child bearing age and effects of social and environmental factors. PLoS Negl Trop Dis. 2014;8(3):e2737. https://doi.org/10.1371/journal.pntd.0002737 eCollection 2014 Mar.

36. Singh S. Congenital toxoplasmosis: Clinical features, outcomes, treatment, and prevention. Trop Parasitol. 2016;6(2):113-22. https://doi.org/10.4103/ 2229-5070.190813

37. Switaj K, Master A, Skrzypczak M, Zaborowski P. Recent trends in molecular diagnostics for Toxoplasma gondii infections. Clin Microbiol Infect. 2005;11: 170-6.

38. Tao Q, Wang Z, Feng $H$, Fang $R$, Nie H, Hu M, Zhou Y, Zhao J. Seroprevalence and risk factors for Toxoplasma gondii infection on pig farms in central China. J Parasitol. 2011;97(2):262-4.

39. Tavassoli M, Ghorbanzadehghan M, Esmaeilnejad B. Foll Detection of Toxoplasma gondii in sheep and goats blood samples by PCR-RFLP in Urmia. Vet Res Forum Winter. 2013;4(1):43-7.

40. Torgerson PR, Mastroiacovo P. The global burden of congenital toxoplasmosis: a systematic review. Bull World Health Organ. 2013;91:501-8.

41. Van der Giessen J, Fonville $M$, Bouwknegt $M$, Langelaar M, Vollema A. Seroprevalence of Trichinella spiralis and Toxoplasma gondii in pigs from different housing systems in The Netherlands. Vet Parasitol. 2007;148:371-4. https://doi.org/10.1016/j.vetpar.2007.06.009.

42. Viera AJ, Garrett JM. Understanding interobserver agreement: the kappa statistic. Fam Med. 2005;37:360-3.

\section{Publisher's Note}

Springer Nature remains neutral with regard to jurisdictional claims in published maps and institutional affiliations.
Ready to submit your research? Choose BMC and benefit from:

- fast, convenient online submission

- thorough peer review by experienced researchers in your field

- rapid publication on acceptance

- support for research data, including large and complex data types

- gold Open Access which fosters wider collaboration and increased citations

- maximum visibility for your research: over $100 \mathrm{M}$ website views per year

At BMC, research is always in progress.

Learn more biomedcentral.com/submissions 